\title{
THE ECONOMIC IMPACT OF THE SOUTH AFRICAN AGRICULTURAL RESEARCH COUNCIL'S DRY BEANS BREEDING PROGRAM
}

\author{
THULA DLAMINI \\ Agricultural Research Council, Pretoria, South Africa \\ LANIER NALLEY* \\ Department of Agricultural Economics, University of Arkansas, Fayetteville, Arkansas \\ FRANCIS TSIBOE \\ Department of Agricultural Economics, University of Arkansas, Fayetteville, Arkansas \\ ANDREW BARKLEY \\ Department of Agricultural Economics, Kansas State University, Manhattan, Kansas \\ AARON SHEW \\ Department of Agricultural Economics, University of Arkansas, Fayetteville, Arkansas
}

\begin{abstract}
This study estimates the dry bean yield increase in South Africa that is attributable to genetic improvements through the Agricultural Research Council's (ARC) bean breeding program. Using 32 test plots across South Africa from 1982 to 2014, results indicate that ARC breeding increased average yields by 11.65 $\mathrm{kg} / \mathrm{ha}$ annually, for a cumulative $43.28 \%$ increase. These yield increases were not at the expense of yield variance, an important measure of food security. These findings indicate that the returns on investment are relatively high (an estimated $5.67: 1$ benefit-cost ratio) and can lead to greater food security though increased and stabilized bean yields.
\end{abstract}

Keywords. Agricultural R\&D, bean breeding, South Africa

JEL Classifications. Q16, Q18

\section{Introduction}

Dry beans (Phaseolus vulgaris L.) are the most-consumed whole food legume globally; therefore, their increased production is central to ensuring food security for many poor households in Africa and Latin America (De Ron, Papa, Bitocchi, 2015; Siddiq and Uebersax, 2012). Dry beans are a great source of

The authors would like to acknowledge the South African Agricultural Research Council (ARC) for their data support and Diana Danforth for her modeling efforts.

*Corresponding author's e-mail: 1lnalley@uark.edu 
protein, complex carbohydrates, and soluble and insoluble dietary fibers and have no cholesterol-all of which are important in sub-Saharan Africa where micronutrient and protein deficiencies are prevalent (Department of Agriculture, Forestry and Fisheries, 2012). Dry beans, often called the "meat of the poor," provide micronutrients to more than 300 million people in the tropics and, in many areas, are the second most important source of calories following maize (Consultative Group on International Agricultural Research [CGIAR], 2016). Given the large population growth rates in sub-Saharan Africa, increases in dry bean yields will need to at least equal or surpass that of population growth to ensure food and micronutrient security.

Breeding programs that are focused on increasing yields, reducing production costs, and maximizing the overall productivity of bean production can help meet the growing demand for food and micronutrients in sub-Saharan Africa. The scientific literature is rich in how cereal breeding programs affect genetic gains, particularly what the breeding impact is on increasing yields (Brennan, 1989a; Dlamini, Magingxa, and Liebenberg, 2015; Feyerherm, Paulsen, and Sebaugh, 1984; Fischer and Wall, 1976; Gollin, 2006; Holland and Bingham, 1994; Nalley, Barkley, and Chumley, 2008a; Nalley et al., 2008b; Traxler et al., 1995; Waddington et al., 1986). However, the research is sparse on quantifying the genetic gains caused by bean breeding programs. Accordingly, this void in the research is critical given that more than 200 million people in sub-Saharan Africa depend on the common bean as their staple crop, and women, the prominent bean growers, sell surpluses to the market to provide additional household income (CGIAR, 2016).

Beans have significant nutritional and agronomic value because they fix nitrogen in the soil in areas where producers cannot afford to purchase external inputs. However, public funding for bean breeding in Africa has been volatile, resulting in shortages of qualified scientific staff and a high turnover of skilled staff because of few professional incentives. These problems, in combination with civil strife, droughts/floods, and political instability have hindered ongoing bean research for prolonged periods of time (Buruchara et al., 2011).

Typically, the bean varieties South African farmers are able to obtain are of low quality and come from miscellaneous genetic sources. In South Africa in 2010 , dry beans accounted for about $80 \%$ of total caloric supply provided by pulses and an estimated daily per capita caloric supply of $25 \mathrm{Kcal}$ (Food and Agriculture Organization of the United Nations [FAO], 2015). Since the 1980s, dry bean yields in South Africa have increased from $984 \mathrm{~kg} / \mathrm{ha}$ in 1972, the initial year of the Agricultural Research Council (ARC) breeding program, to 1,200 $\mathrm{kg} / \mathrm{ha}$ in 2013 (FAO, 2015). This yield increase equates to a $116.17 \%$ increase from 1972 to 2014 , or a $3.71 \%$ increase per year. These gains in dry bean yield may be attributed to genetic improvement, improved agronomic management practices, and climatic factors. Gains from agronomic management are attributed to improvements in the efficiency in the use of fertilizer, pesticides, fungicides, or 
other factors that are not embodied in the seed. On the other hand, genetic gains are associated with improvements through breeding (manipulation of genetic factors within the seed). Furthermore, climatic factors such as rainfall amount and distribution, temperature, and incident radiation have significant influence on dry bean yields. However, until now, the gains in dry bean yield have not been disaggregated into agronomic and genetic gains, which would aid in understanding the difference between general trends in better agricultural production and those brought on from publically supported genetic breeding programs.

The growth in South Africa's dry bean production is partially attributable to past investments in dry bean research, specifically the ARC dry bean breeding program. In South Africa, the ARC is a government institution that conducts agricultural research, develops human capital, and fosters innovation to support and develop the agricultural sector. As a part of its activities, the ARC's Grain Crops Institute has conducted dry bean breeding since the 1970s. Particularly, the ARC breeding program focuses on two major breeding components: yield enhancement and disease (bacterial and fungal) resistance. Since the 1970s, the ARC breeding program has released 21 varieties of dry beans that are resistant to diseases such as bacterial brown spot, halo blight, and bacterial blight; see Table A1 in the online supplementary appendix for the characteristics of the varieties released by ARC-Grain Crops Institute.

Funding for the ARC is derived from the following sources: (1) the South Africa Parliamentary Grant (68\%); (2) external income (revenue derived from project contracts, research and development contracts, sale of farm products, and royalty income; $30 \%$ ); and (3) other income (interest received from short-term investments; $\%$ ) (ARC, 2014a). It was estimated that the ARC's infrastructure, capital replacement, and maintenance costs required a capital injection of more than 480 million South African Rand (R 480 million) in 2014 (ARC, 2014a). These investments in infrastructure and capital equipment enabled the ARC to continue to effectively conduct agricultural research, develop human capital, and foster innovation to support and enhance the agricultural sector.

Although there are large up-front fixed costs to any breeding program (labs, equipment, etc.) as producer's increase adoption of ARC bean varieties $(17.21 \%$ annually since 1992; Crop Estimates Committee, 2015), producers also rely on subsequent releases that address evolving biotic and abiotic stresses, which require further funding. Given the fact that the ARC breeding program is publicly funded and competes for that funding against other agricultural research programs, information demonstrating the economic impacts of the ARC breeding program, both from a per hectare and an aggregate standpoint, is necessary to make relative comparisons of public agricultural investments. Accordingly, this study could potentially inform the government and the taxpayers of South Africa about the ARC breeding program's net benefits to consumers and producers. Furthermore, showing the program benefits to its constituents is crucial in maintaining and increasing funding levels in an effort to combat food insecurity. 
Although most breeding programs focus on yield enhancement, targeting a reduction in yield variability in low-income countries may be equally beneficial to both producers and consumers, as it generally reduces price instability within markets (Nalley and Barkley, 2010). Correspondingly, Gollin (2006) highlights three ways for improving yield stability: (1) breeding for improved disease or pest resistance in modern varieties; (2) replacing traditional varieties with higher-yielding modern varieties, which in effect could have lower relative yield variability; and (3) diffusing multiple varieties that differ in their susceptibilities to disease and resistance to pests. Critics of modern varieties have suggested the yields of these varieties, although higher, vary more across growing seasons than traditional varieties in low-income countries, thereby exposing consumers and producers to greater economic risks.

To explain further, Timmer (1998) states that food security is a function of many short-term dimensions; he specifically discusses food price stability as one of these short-term factors. Yield stability (or variance reduction) benefits food producers because it reduces the risks they incur in production from season to season. This risk reduction leads producers to increase investments in new technologies that are designed to increase overall productivity. Timmer (1998) also found that consumers benefit from stable food prices because they do not face the risk of sudden and sometimes sharp reductions in real income as a result of price shocks. This kind of benefit accrues disproportionately to the poor because they spend a larger portion of their budget on food. Thus, the benefits to the consumer from price stabilization have a significant equity dimension, which can play an important role in poverty alleviation. Ideally, the ARC would like to increase yield and decrease yield variability for the purpose of creating more price stability, which could in effect eliminate some of the factors at play in food insecurity.

In light of this, the first objective of this study is to determine the proportion of the yield increases attributable to genetic enhancements of ARC-released dry bean varieties, while holding the agronomic management changes constant from 1982 to 2014 with data from 32 test plots across South Africa. The second aim is to determine whether modern dry bean varieties released by ARC have influenced yield variability within the same time period. In addition to quantifying the evolution of the yields and the yield variance from the release of ARC varieties, the third objective of this study is to calculate the economic benefits of the ARC breeding program for local South African bean producers.

Prior research on the impacts of bean research (Evenson, 2003; Johnson, Pachico, and Wortmann, 2003; Kalyebara et al. 2008; Larochelle et al., 2015) studied total (genetic and agronomic) gains without separating the two. Often, a large portion of yield gains is attributable to management practices, thus "inflating" the impact of breeding programs. In fact, CGIAR stated that through its breeding efforts in low-income countries, high growth rates from varietal/genetic improvements were realized in all crops except beans, suggesting that gains may be a result of management practices as well as genetic enhancements. 
Correspondingly, Evenson and Gollin (2003) state that beans have effectively been "crowded out" of productive areas in Latin America and Africa by crops with greater genetic improvements, specifically maize and soybeans.

This study is relevant given the fact that like most governments, South Africa must allocate limited funds to agricultural research and without tangible evidence as to what return on investment it is obtaining from funding a bean breeding program when money could flow to other crops. To illustrate, the economic justification of agricultural research in other low-/middle-income countries is uncertain; so, the more information given to governments, private donors, and public breeders on the impact of breeding, the better each institution is at making informed investment decisions. Moreover, the ARC, whose germplasm is released to help poor producers and consumers, will need to ensure that the economic benefits of their modern lines, which enhance yield potential and lower yield variance, outweigh the program costs in feeding a growing population.

\section{Methodology and Data}

\subsection{Data}

Each year, commercially available and new dry bean cultivars are evaluated in different environments for yield potential, adaptation, and disease resistance by the ARC. These performance test data are required for decisions on the release and seed production of new cultivars by seed companies and for cultivar recommendations to farmers. Trials are compiled by ARC and distributed to approximately 30 localities throughout the dry bean production regions of South Africa (Free State, North West, KwaZulu Natal, Mpumalanga, and Limpopo), and they are planted by seed firms, cooperatives, agricultural companies, farmers (strip trials on their actual fields), and research stations during October/November of each trial year.

The seeds are planted by hand or with planters-recommended spacing for the trials was $750 \mathrm{~mm}$ between rows and $75 \mathrm{~mm}$ within rows, resulting in about 170,000 seeds/ha. Enough seed for four rows of $5 \mathrm{~m}$ per plot was supplied for each plot, and the middle two rows were harvested, leaving the last plant at the end of each row to eliminate any border effects. Although cultural practices vary somewhat across participant and production locations, each bean trial is produced under normal farming practices for a given region, and all trials are visited by ARC staff to monitor growth and production practices. Additionally, nitrogen, phosphorus, and potassium fertilizers are applied to the fields at an average annual rate of $42.30 \mathrm{~kg} / \mathrm{ha}, 22.34 \mathrm{~kg} / \mathrm{ha}$, and $18.43 \mathrm{~kg} / \mathrm{ha}$, respectively. Figure 1 indicates the location of the test plots used in the study.

The ARC bean breeding program concentrates on two main dry bean types: small white canning (SWC) and red speckled (RS). The SWC bean varieties are used for canning purposes and have canning attributes, such as (1) low moisture 


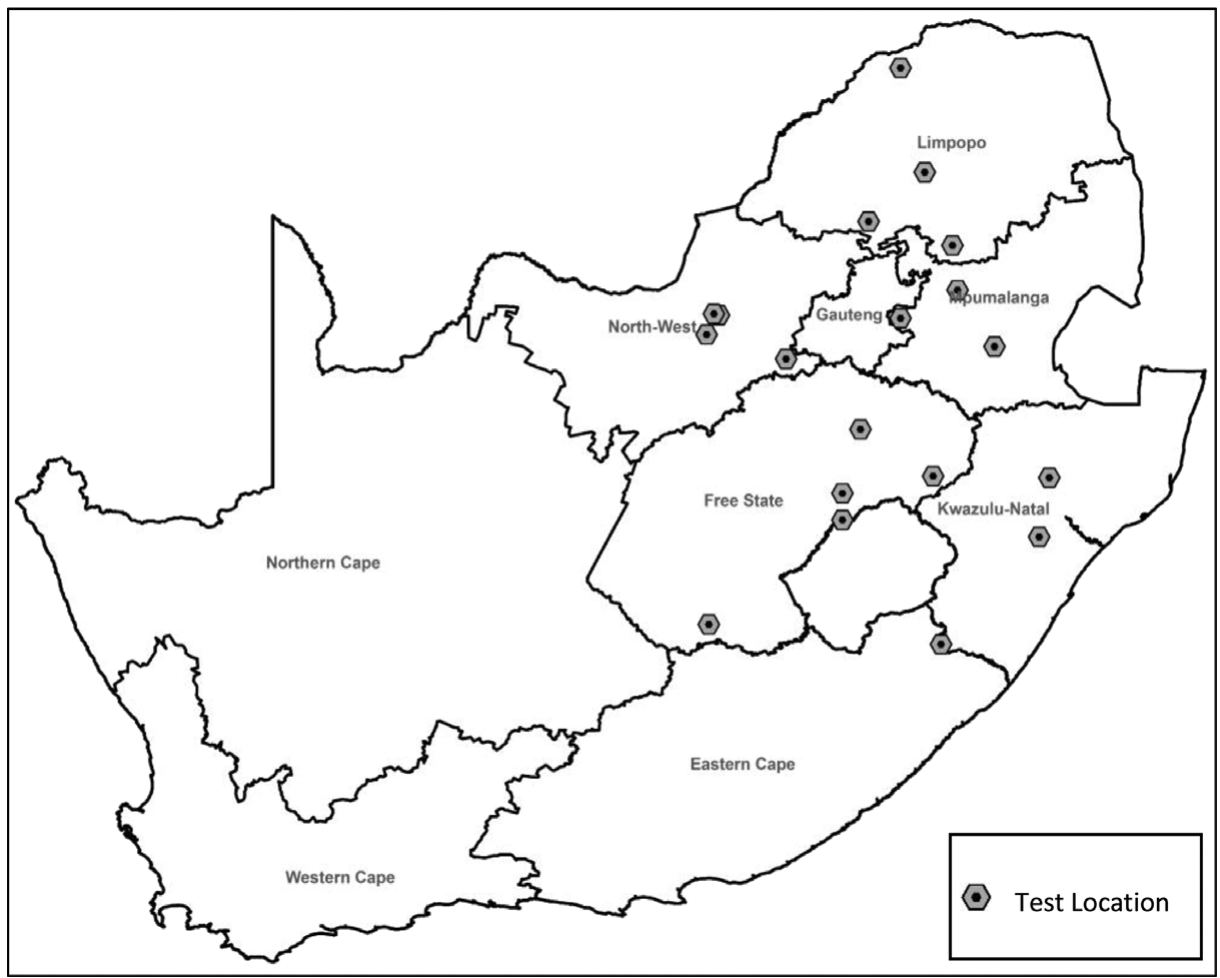

Figure 1. Agricultural Research Council Dry Bean Trial Locations Used in the Data Set

content of approximately $8 \%$ or less, (2) low levels of splitting (not higher than $9 \%$ ), and (3) a water uptake of an $80 \%$ maximum, and have determinate growth (growth habit I: flowers at the ends of branches, which stops stem growth after flowering). In addition, SWC cultivars have upright growth and are usually higher yielding than RS (ARC, 2014b). Unlike the SWC cultivars, RS cultivars have indeterminate growth and have few short and upright branches. In addition, RS cultivars grow after flowering and are almost always inclined to lodging; hence, they have lower yields than do SWC cultivars. The RS cultivars are relatively softer than SWC and cook in a short period of time (ARC, 2014b). As such, households throughout South Africa prefer RS to SWC bean types when making dry bean soups, stews, salads, and so forth. About $61 \%$ of the observations in the data set (available in the online supplementary appendix) are of the RS bean type, and the remaining $38.74 \%$ are of the SWC bean type. Table A1 reports characteristics of bean varieties included in the data set. The average yield by variety and location are presented in Table A2.

Optimally, weather data (temperature, relative humidity, solar radiation, vapor pressure deficit, etc.) would have been collected and used in the analysis, 
but these data were not available for this data set. ${ }^{1}$ Lobell, Cassman, and Field (2009) stated that one must conduct experiments over many years to ensure the mean yield estimate reflects a typical range of weather variation. As a caveat to this claim, localized weather outcomes could be controlled for if the time series dimension of the data is small. Thus, although actual weather observations are preferred, some of the scientific literature (Tack, Barkley, and Nalley, 2015) suggests that year and location fixed effects can simulate a "typical" growing year if the data set is large enough. To demonstrate how the data set used in this study varied over time and location, box plots over trial years are presented in Figure A1 in the online supplementary appendix. The vertical height of each box plot represents the cross-sectional variation across varieties and locations within each trial year, and the sequence of boxes demonstrates variation across years, which could be taken as the common weather shocks across locations.

\subsection{Conceptual Framework}

The methodology used to calculate the economic benefits of the ARC breeding program followed extensive literature on the economic impacts of agricultural research, as summarized by Huffman and Evenson (2006) and Alston, Norton, and Pardey (1995). Previous evaluations of agricultural breeding programs are exemplified in the literature (Brennan 1989b; Maredia, Bernsten, and Ragasa, 2010; Nalley, Barkley, and Chumley, 2008a; Nalley et al., 2008b; Traxler et al. 1995). Brennan (1989b) evaluated the impacts of breeding programs at different stages, which further extended the applications of this type of analysis. With this in mind, our first step in evaluating the economic impact of the ARC breeding program was to measure the proportion of yield increases attributable to genetic improvements, holding all other factors, such as agronomic conditions, management practices, and weather, constant.

The use of relative yield performance data from test plots implicitly assumes that actual producer yields are equivalent to test plot yields in the trials. Annual changes in relative yields are measured with performance test data, which represent ideal management and agronomic conditions, instead of actual dry bean yield performance. Although a gap between experimental and actual yields exists, Brennan (1984) states that the only reliable sources of relative yields are variety trials. Thus, the absolute yield/yield variance could be higher/lower on test plots, and the relative difference should be the same between test plots and producers' fields. The genetic contribution of the ARC breeding program was measured by quantifying the increase in yields attributable to genetic enhancements for the period from 1982 to 2014. Salmon (1951) reported that tests over many location-years are necessary to accurately detect differences in

\footnotetext{
1 Precipitation (total) was available for some years but was omitted from the model because of sporadic data availability.
} 
Table 1. Relative Yield Advantages of Agricultural Research Council (ARC) Varieties, 19722012

\begin{tabular}{|c|c|c|c|c|c|c|c|}
\hline Variety & $\begin{array}{l}\text { Average } \\
\text { Yield } \\
(\mathrm{kg} / \mathrm{ha})\end{array}$ & $\begin{array}{l}\text { Yield } \\
\text { Ratio }^{\mathrm{a}}\end{array}$ & $\begin{array}{l}\text { Coefficient } \\
\text { of Variation } \\
(\%)\end{array}$ & $\begin{array}{l}\text { Yield } \\
\text { Difference } \\
(\mathrm{kg} / \mathrm{ha})^{\mathrm{b}}\end{array}$ & $\begin{array}{l}\text { Year } \\
\text { Released } \\
\text { to Public }\end{array}$ & $\begin{array}{l}\text { Number of } \\
\text { Observations }\end{array}$ & $\begin{array}{l}\text { Red } \\
\text { Speckled }\end{array}$ \\
\hline Bonus & 1,883 & - & 57.58 & - & 1972 & 439 & Yes \\
\hline Teebus & 2,040 & 1.08 & 50.43 & 157 & 1976 & 411 & No \\
\hline Kamberg & 2,352 & 1.25 & 47.07 & 469 & 1982 & 230 & No \\
\hline Helderberg & 2,240 & 1.19 & 39.10 & 358 & 1990 & 155 & No \\
\hline Stomberg & 1,950 & 0.90 & 49.47 & -183 & 1990 & 196 & Yes \\
\hline Kranskop & 1,874 & 1.00 & 47.59 & -8 & 1993 & 114 & Yes \\
\hline Jenny & 1,981 & 1.05 & 46.39 & 99 & 1995 & 260 & Yes \\
\hline OPS GH1 & 2,441 & 1.30 & 34.75 & 559 & 1996 & 51 & Yes \\
\hline OPS RS1 & 2,012 & 1.07 & 43.46 & 130 & 1996 & 208 & Yes \\
\hline OPS-KW 1 & 2,105 & 1.07 & 44.27 & 132 & 1997 & 157 & No \\
\hline OPS-RS 3 & 2,074 & 1.10 & 44.85 & 191 & 1999 & 51 & Yes \\
\hline OPS RS 4 & 2,219 & 1.18 & 44.38 & 337 & 2001 & 135 & Yes \\
\hline RS 5 & 1,982 & 1.05 & 49.73 & 99 & 2002 & 132 & Yes \\
\hline Teebus RR1 & 2,228 & 1.18 & 43.62 & 346 & 2002 & 102 & No \\
\hline Kranskop HR1 & 2,141 & 1.14 & 44.94 & 258 & 2003 & 96 & Yes \\
\hline Teebus RCR2 & 1,800 & 0.96 & 47.84 & -83 & 2005 & 53 & No \\
\hline Sederberg & 1,699 & 1.04 & 52.75 & 67 & 2006 & 55 & Yes \\
\hline RS6 & 2,260 & 1.20 & 44.12 & 377 & 2008 & 41 & No \\
\hline Tygerberg & 2,620 & 1.39 & 22.55 & 737 & 2010 & 4 & Yes \\
\hline Kamiesberg & 2,195 & 1.17 & 55.57 & 312 & 2011 & 24 & Yes \\
\hline RS 7 & 2,384 & 1.27 & 44.24 & 501 & 2012 & 14 & Yes \\
\hline
\end{tabular}

${ }^{a}$ Mean values of the ratio of the yield of each variety to the yield of the control variety (Bonus) for all locations and years. A larger value indicates a higher yield relative to the control variety.

${ }^{b}$ Calculated by subtracting the mean yield of each variety from the mean yield of the control variety (Bonus).

variety yields. With this in mind, the yield data were aggregated over all locations and years to develop a yield ratio for each variety.

Following Feyerherm, Paulsen, and Sebaugh (1984), the relative yield ratios were derived by calculating the mean yield ratio between the first released variety (Bonus, released in 1972) and the subsequent varieties, over all locationyears. For ease of interpretation, the yield differences were also calculated by subtracting the mean yield $(\mathrm{kg} / \mathrm{ha})$ of each variety from that of Bonus. The yield ratio and yield differential provide comparisons of varietal performance (Table 1). Table 1 shows that since the release of Bonus in 1972, yields have improved for 17 out of 20 of the released varieties. The only exceptions to this are Stomberg, Kranskop, and Teebus RCR2, released in 1990, 1993, and 2005, respectively. Although the Feyerherm, Paulsen, and Sebaugh (1984) method allows for the estimation of relative yield differences, it does not account for differences in breeding objectives; that is, a variety might be bred for resistance to a fungus such as the common mosaic necrosis virus in beans, or it might be bred 
for maximum yield and yield stability. Therefore, to incorporate this objective of yield stability, the Just and Pope (1979) method was applied.

The Just-Pope production function offers flexibility in describing a stochastic technological process that might exhibit changes in the mean and the probability distribution of output. This method provides a straightforward procedure for testing the effects of increased yield on yield stability. ${ }^{2}$ Specifically, the Just-Pope production function allows the inputs to affect both the mean and variance of the outputs. The production function is as follows:

$$
Y_{i l t}=f\left(\boldsymbol{X}_{i l t}, \beta\right)+h\left(\boldsymbol{X}_{i l t}, \alpha\right) \varepsilon_{i l t},
$$

where $Y_{i l t}$ is yield of the $i$ th varietal test at location $l$ and in time $t, X_{i l t}$ represents explanatory variables, $\beta$ and $\alpha$ are parameter vectors, and $\varepsilon_{i l t}$ is the customary error term with a mean of zero. The first term, $f\left(\boldsymbol{X}_{i l t}, \beta\right)$, on the right-hand side of equation (1) captures other factors affecting the mean output, whereas the second term, $h\left(\boldsymbol{X}_{i l t}, \alpha\right) \varepsilon_{i l t}$, captures factors affecting the output variance $\left(\sigma_{i l t}^{2}\right)$.

An advantage of the Just-Pope production function is its correction of multiplicative heteroskedasticity, which is important for varietal traits because of the variations in both of the species (RS vs. SWC) and in the breeding goals (yield, disease resistance, etc.) across varieties. Notably, because of these stated differences in the breeding program across time, the error terms across varieties may be heteroskedastic in nature. As such, by using the Just-Pope production function, we account for the heterogeneity in breeding goals across varieties. Thus, if output variance $\left(\sigma_{i l t}^{2}\right)$ is an exponential function of $K$ explanatory variables, the general model with heteroskedastic errors can be written as follows:

$$
\begin{gathered}
Y_{i l t}=X_{i l t}^{\prime} \beta+e_{i l t}, \\
E\left(e_{i l t}^{2}\right)=\sigma_{i l t}^{2}=\exp \left[X_{i l t}^{\prime} \alpha\right],
\end{gathered}
$$

where $X_{i l t}^{\prime}=\left(x_{1 i l t}, x_{2 i l t}, \ldots, x_{k i l t}\right)$ is a row vector of observations on the $K$ independent variables. The vector $\alpha=\left(\alpha_{1 i l t}, \alpha_{2 i l t}, \ldots, \alpha_{k i l t}\right)$ is of the dimension $(K \times 1)$ and represents the unknown coefficients. $E\left(e_{i l t}\right)=0$ and $E\left(e_{i l t} \cdot e_{j l t}\right)=0$ for $i \neq j$. Equation (3) is rewritten as

$$
\ln \sigma_{i l t}^{2}=X_{i l t}^{\prime} \alpha,
$$

where $\sigma_{i l t}^{2}$ is unknown, but the marginal effects of the explanatory variables on the variance of production, using the ordinary least squares (OLS) residuals from

2 Another approach to estimation is the generalized method of moments. Although this estimation strategy has its advantages, it requires instruments that are orthogonal to the error term $\varepsilon_{i}$, which were not identifiable. 
equation (2), can be estimated such that

$$
\ln \hat{e}_{i l t}^{2}=X_{i l t}^{\prime} \hat{\alpha}+\mu_{i l t},
$$

where $\hat{e}_{i l t}$ represents predicted values of $e_{i l t}$ from the least squares estimation of equation (2). The error term $\mu_{i l t}$ is calculated by solving equations (4) and (5) for $\mu_{i l t}$. The output variance $\left(\sigma_{i l t}^{2}\right)$ is calculated from the estimation of equation (5), which provides estimates of

$$
\mu_{i l t} \cdot \mu_{i l t}=\ln \left(\hat{e}_{i l t}^{2} / \sigma_{i l t}^{2}\right) .
$$

The predicted values from equation (5) are used as weights for estimating generalized least squares coefficients for the mean output in equation (2). That is, the estimates from equation (5) can be viewed as the effects of the independent variables on yield variability $\left(\sigma_{i l t}^{2}\right)$. The predicted values from equation $(5)$ are then used as weights when reestimating equation (2). Thus, the results from the reestimation of equation (2) with the weights from the error terms of equation (5) provide the effects of the independent variables on yield.

\subsection{Empirical Model Specification}

The mean and variance of yield are specified as a function of the release year (RLYR) of each variety, which can be interpreted as the "vintage" of a breeding technology (Arrow, 1962; Nalley et al., 2008b; Traxler et al., 1995). The coefficient on the RLYR captures the progression of the breeding technology across time and is the main parameter for measuring the impact (yield and yield variance) of the breeding program. However, a distinction exists between RLYR, which varies from 1972 to 2012, and the trial date, which varies from 1990 to 2014. Each variety has a single RLYR, the date that the variety was released to the public for planting, and each one embodies the breeding technology for that specific year. In the estimated multiple regression model, the coefficient on RLYR only captures the effect of dry bean seed technology at the specific year of release. A typical life cycle of a variety is one of relatively higher yields than previously released varieties in the early years of adoption, then the eventual replacement with yet higher yielding releases (Nalley et al., 2008b).

RLYR is not a time-trend variable but is modeled similarly to the way in which Arrow's (1962) growth model showed the embodied technology (Traxler et al., 1995). Specifically, Arrow (1962) assigned "serial numbers" of ordinal magnitude to the embodied technology in capital. In this model, the variable RLYR represents the embodied technology for a given year of release by the breeding program. This method is standard procedure for measuring the impact of technological change on output (Nalley et al., 2008b). In addition to the RLYR, the mean and variance of yield were also modeled as a function of whether variety $i$ was an $\mathrm{RS}$ variety $(R S)$.

Ideally, precipitation, solar radiation, and temperature would enter the yield models given that bean yields are a function of climatic data. However, like the 
Table 2. Regression Results from Ordinary Least Squares (OLS) and Just-Pope Production Functions

\begin{tabular}{llll}
\hline \hline & \multicolumn{1}{c}{$(1)$} & \multicolumn{1}{c}{$(2)$} & \multicolumn{1}{c}{$(3)$} \\
Variable & OLS Yield & Just-Pope Yield & Just-Pope Variance \\
\hline Intercept & $-20,787.00(3,486.00)^{* *}$ & $-21,262.22(2,574.86)^{* * *}$ & $11.63(8.39)$ \\
RLYR & $11.42(1.74)^{* *}$ & $11.65(1.28)^{* * *}$ & $0.00(0.00)$ \\
Red speckled & $-155.45(34.89)^{* *}$ & $-156.76(39.97)^{* * *}$ & $0.04(0.08)$ \\
Free State & $109.59(48.08)^{* *}$ & $111.40(155.29)$ & $-0.26(0.12)^{*}$ \\
KwaZulu Natal & $208.41(47.44)^{* * *}$ & $204.87(195.38)$ & $0.39(0.11)^{* *}$ \\
Mpumalanga & $262.53(48.86)^{* *}$ & $263.49(168.28)$ & $0.05(0.12)$ \\
Limpopo & $503.16(151.03)^{* *}$ & $516.82(668.42)$ & $0.98(0.36)^{* *}$ \\
Adjusted $R^{2}$ & 0.23 & 0.24 & 0.06 \\
\hline \hline
\end{tabular}

Notes: Significance levels are as follows: ${ }^{*} P<0.1,{ }^{* *} P<0.05,{ }^{* * *} P<0.01$. Standard errors in parentheses are adjusted for clustering by Year. Year fixed effects are shown in Table A3 in the online supplementary appendix. RLYR, release year.

majority of large panel data sets from low-/middle-income countries, weather data were not available. Year (Year) and location $(\boldsymbol{L} \boldsymbol{o c})$ fixed effects were used to account for weather and cluster the standard errors by Year. Additionally, the year and location fixed effects account for differences in farm structure across time and location, respectively. The location variables entered the models as dummies: Free State, North West, KwaZulu Natal, Mpumalanga, and Limpopo, with Gauteng acting as the control location. Likewise, growing years were also modeled as dummies, with 1981 as the control. Therefore, the estimated models for yield $\left(Y_{i}\right)$ in kilograms per hectare and the log variance of yield $\left(\hat{e}_{i}^{2}\right)$ are as follows:

$$
\begin{gathered}
Y_{i}=\beta_{1} R L Y R_{i}+\beta_{2} R S+\boldsymbol{\beta}_{3} \text { Loc }_{i}+\boldsymbol{\beta}_{4} \text { Year }_{t}+e_{i} \\
\ln \hat{e}_{i}^{2}=\delta_{1} R L Y R_{i}+\delta_{2} R s+\boldsymbol{\delta}_{2} \text { Loc }_{i}+\boldsymbol{\delta}_{3} \text { Year }_{t}+\mu_{i} .
\end{gathered}
$$

\section{Results}

The results from the Just-Pope model are shown in Table 2, which includes the effects on yield and on yield variance, as well as the OLS estimates. The coefficients of fixed effects for each growing year included in the models are resented in Table A3. The magnitude of the coefficient of determination $\left(R^{2}\right)$ shows that $23 \%(6 \%)$ of the variation in mean yield (yield variance) is explained by the independent variables in the model. The variable RLYR is the focus in this study because it captures the "vintage" of each variety, or the level of technology that characterizes each bean variety. The results from the Just-Pope model (Table 2, "Just-Pope Yield") indicate that from 1982 to 2014, the ARC breeding program significantly $(P<0.01)$ increased the annual average dry bean 
yields by $11.65 \mathrm{~kg} / \mathrm{ha}$, which is equivalent to $1.03 \%$ annually $(11.65 / 1130.78$, where $1130.78 \mathrm{~kg} / \mathrm{ha}$ is the average yield for dry beans over the time period under investigation; FAO, 2015). During the period from 1972 to 2014, the ARC breeding program contributed $489.36 \mathrm{~kg} / \mathrm{ha}$ cumulatively $(11.65 \times 42)$ to dry bean yields, which is equivalent to a $43.28 \%(489.36 / 1130.78)$ increase in producer yields attributed to genetic enhancement from the program. These estimates are larger (63\%) than those estimated by Singh et al. (2007) who found 75 years of breeding dry beans in the western United States was associated with a $0.65 \%$ gain in yield annually. For similar studies on wheat and rice, Nalley, Barkely, and Chumley (2008a) and Nalley et al. (2008b) showed that rice breeding programs in the United States and wheat breeding programs in Mexico increased yields by $0.42 \%$ and $0.46 \%$, respectively.

With regard to yield variance, this study shows that from 1982 to 2014 the varieties released by the ARC breeding program experienced no significant $(P$ $>0.05$ ) change in annual yield variance (Table 2, "Just-Pope Variance"). To give some credence to this finding, we regressed the calculated coefficient of variation $(\mathrm{CV})$ on RLYR shown in Table 1 . The results showed that RLYR was not statistically different from zero. This, along with the fact that the findings from the Just-Pope model imply that yield risk (as measured by the CV) is going down, indicates that ARC-released bean variety yields have increased without raising the risk to producers.

Table 3 presents the estimates of the genetic and economic benefits of the ARC breeding program for dry bean producers in South Africa (all monetary values are in 2014 terms). The study assumes a perfectly elastic demand for dry beans in South Africa, which is a realistic assumption given that South Africa produces a small portion of the global dry bean supply (FAO, 2015), and the yield increase is a relatively small shift in the total domestic supply, let alone the world supply. Thus, increased South African dry bean production as a result of genetic improvement is assumed not to influence the global price of dry beans. To illustrate, the genetic gains in Table 3 are calculated from the results (RLYR) of the regression model in Table 2. An important part of calculating genetic gains associated with a breeding program is to take into account the cumulative effects of the program over the entire period. That is, the yield gains attributable to the breeding program in 2014 are those observed in that year and the previous year (2013). Therefore, the genetic gains for 2014 would be the sum of the yearspecific genetic gain from 1972 to 2014. The annual and cumulative genetic gains for the ARC breeding program are listed in Table 3. Dry bean producers in South Africa received an average annual economic benefit of $\mathrm{R} 31$ million (in 2014 terms) from the ARC breeding program during the 1992-2014 period. This benefit is a function of several exogenous factors (acreage, price, adoption rate, etc.) and the endogenous factor of genetic gains attributed to the ARC breeding program. The average economic benefits South African producers have received for the decade 2004-2014 are estimated at R 27.35 million annually. 
Table 3. Per Hectare Cumulative Genetic Gains Associated with the Agricultural Research Council (ARC) Dry Beans Breeding Program, 1972-2012

\begin{tabular}{|c|c|c|c|c|c|c|}
\hline Year & $\begin{array}{l}\text { Cumulative } \\
\text { Genetic Gain } \\
(\mathrm{kg} / \mathrm{ha})\end{array}$ & $\begin{array}{l}\text { Hectares of } \\
\text { Beans in South } \\
\text { Africa }\end{array}$ & $\begin{array}{l}\text { ARC } \\
\text { Adoption } \\
\text { Rates (\%) }\end{array}$ & $\begin{array}{l}\text { Additional } \\
\text { Production from } \\
\text { ARC }(\mathrm{kg})\end{array}$ & $\begin{array}{l}\text { Real } \\
\text { Price } \\
(\mathrm{R} / \mathrm{kg})^{\mathrm{a}}\end{array}$ & $\begin{array}{l}\text { Economic } \\
\text { Gains } \\
(\mathrm{R} / \text { year })^{\mathrm{a}}\end{array}$ \\
\hline 1992 & $233.03^{b}$ & 53,594 & 4.60 & 574,488 & 7.20 & $4,136,831$ \\
\hline 1993 & 244.68 & 46,888 & 6.10 & 699,822 & 6.36 & $4,447,699$ \\
\hline 1994 & 256.33 & 54,500 & 8.03 & $1,121,789$ & 6.09 & $6,837,255$ \\
\hline 1995 & 267.98 & 59,052 & 3.20 & 506,395 & 7.69 & $3,893,424$ \\
\hline 1996 & 279.63 & 56,431 & 7.41 & $1,169,294$ & 6.83 & $7,991,257$ \\
\hline 1997 & 291.28 & 47,000 & 8.40 & $1,149,989$ & 6.77 & $7,789,147$ \\
\hline 1998 & 302.94 & 38,805 & 9.45 & $1,110,886$ & 7.17 & $7,961,207$ \\
\hline 1999 & 314.59 & 64,800 & 18.77 & $3,826,762$ & 7.51 & $28,744,495$ \\
\hline 2000 & 326.24 & 71,800 & 14.18 & $3,321,125$ & 7.04 & $23,384,359$ \\
\hline 2001 & 337.89 & 77,950 & 12.87 & $3,389,502$ & 5.79 & $19,625,374$ \\
\hline 2002 & 349.54 & 44,900 & 14.10 & $2,212,547$ & 8.59 & $19,000,444$ \\
\hline 2003 & 361.19 & 51,010 & 20.56 & $3,787,752$ & 7.62 & $28,860,206$ \\
\hline 2004 & 372.84 & 56,200 & 7.23 & $1,513,912$ & 6.25 & $9,460,996$ \\
\hline 2005 & 384.49 & 49,300 & 9.09 & $1,723,064$ & 5.37 & $9,246,879$ \\
\hline 2006 & 396.15 & 54,880 & 4.27 & 928,320 & 7.28 & $6,758,188$ \\
\hline 2007 & 407.80 & 50,725 & 35.78 & $7,401,284$ & 9.91 & $73,373,670$ \\
\hline 2008 & 419.45 & 43,800 & 30.00 & $5,511,559$ & 10.26 & $56,528,963$ \\
\hline 2009 & 431.10 & 43,800 & 29.30 & $5,532,483$ & 8.27 & $45,733,008$ \\
\hline 2010 & 442.75 & 44,100 & 23.70 & $4,627,508$ & 8.01 & $37,087,298$ \\
\hline 2011 & 454.40 & 41,900 & 29.20 & $5,559,530$ & 8.03 & $44,629,571$ \\
\hline 2012 & 466.05 & 39,750 & 30.70 & $5,687,378$ & 11.46 & $65,175,438$ \\
\hline 2013 & 477.71 & 43,550 & 28.70 & $5,970,773$ & 12.79 & $76,362,139$ \\
\hline 2014 & 489.36 & 55,820 & 35.90 & $9,806,413$ & 12.58 & $123,324,068$ \\
\hline Total & & & & & & $710,351,916$ \\
\hline
\end{tabular}

${ }^{a}$ Values in 2014 South African Rand (R); deflated with consumer price index retrieved from International Monetary Fund (2015).

${ }^{\mathrm{b}}$ The variety Bonus was released in 1972, but holistic bean production data in South Africa did not begin until 1992. Thus, the cumulative gain between 1972 and 1992 is $233.03 \mathrm{~kg} / \mathrm{ha}$ (the Just-Pope release year [RLYR] coefficient from Table 2 [11.65] multiplied by 20 years).

Note: Constructed using data provided by ARC and RLYR estimate from Table 2.

To ascertain the benefit-cost ratio of the ARC breeding program, the annual cost of running the program for the period 1980 to 2014 was sourced from the ARC. The data sourced from the ARC indicated that on average the ARC breeding program cost about $\mathrm{R} \mathrm{3,502,000} \mathrm{in} 2014$ terms annually. Using the annual cost data and the estimated annual economic benefits, the benefit-cost ratio was estimated to be $5.67: 1$, using an annual average interest rate on savings of $3.65 \%$ (from 2000 to 2012, retrieved from International Monetary Fund [2015]) as a proxy for a discount rate to calculate the discounted cost and benefits, while also accounting for the 12-year lag between the initial cross and release year. That is, for each South African Rand of public funds invested in the ARC breeding program, there is R 5.67 in benefits. Similarly, the calculated 
benefits for every Rand invested in the ARC breeding program are R 9.48 and $\mathrm{R}$ 3.16 , respectively, using the same assumptions as previously, but with minimum and maximum discount rates of $1.27 \%$ and $6.46 \%$ for the same period.

In the literature, the internal rate of return (IRR) to investments is a measure to gauge research effectiveness. The IRR is computed as the discount rate resulting in a value of zero for the net present value. See Alston et al. (2000) and Evenson (2001) for inventories and a meta-analysis of IRRs derived from agricultural research studies. In addition, previous studies estimating the IRR on the expenditures of various components of the ARC have shown that the IRRs on investments in research on the production improvement of animals and cereal (maize, sorghum, and wheat) range between $11 \%-16 \%$ and $28 \%-63 \%$, respectively, per annum, regardless of methodology or the level of aggregation (Thirtle et al., 1998). Similarly, Dlamini, Magingxa, and Liebenberg (2015) showed that the IRR for the ongoing ARC national variety trials for sorghum, sunflower, soybeans, and dry beans is $16 \%$ per annum.

According to Hurley, Rao, and Pardey (2014), the IRRs reported by a vast majority of studies are perceived by policy makers to be implausibly high. As such, to obtain more credible rates of return estimates, Hurley, Rao, and Pardey (2014) developed the modified internal rate of return (MIRR). The MIRR is interpreted as the annual compounding interest rate paid by an investment and is directly related to the benefit-cost ratio. Hurley, Rao, and Pardey (2014) compared the IRR reported by 372 separate studies from 1958 to 2011 with each of their counterpart recalibrated MIRRs. They showed that the MIRR produces a more modest rate of return as compared with the IRR (median of $9.8 \%$ vs. $39 \%$ per year). In light of this, computing the MIRR for the ARC breeding program indicates an $8.92 \%$ return on investments. Although the calculated IRR and MIRR may seem low relative to the IRRs calculated for other components of the ARC and elsewhere, this is partly because of the small area sown to beans relative to other crops in South Africa.

Ideally, the evaluation of any breeding program would be all encompassing; however, like most other evaluations, this study does not account for maintenance breeding. Maintenance breeding generally results in biotic or abiotic resistance for a crop specimen, which may not push up the yield ceiling but raises the yield floor. Productivity enhancement in this study and traditionally is estimated in terms of yield gains and increased total supply, whereas productivity maintenance is measured in terms of the yield losses avoided through embedded seed technology. Economists and policy makers tend to undervalue the productivity losses that can be avoided by utilizing informative agricultural research like maintenance breeding. Accordingly, the substantial economic benefit that accrues from avoided yield losses through resistance to biotic and abiotic stresses is often forgotten in the cost-benefit analysis of such breeding programs.

Previous studies (Marasas, Smale, and Singh, 2003) on breeding programs have estimated the economic impact of a research program's breeding efforts 
for pathogen resistance (maintenance breeding) can be as great if not greater than the impact of increased yields. Previous research (Strauss, 1999; Strauss and Killian, 1996) in South Africa has shown bean yields can increase by 1.4 to 6.8 times that of an unsprayed variety susceptible to rust (caused by Uromy-I ces appendiculatus) when controlled via fungicide or through genetic resistance. Thus, there are large economic gains associated with the ARC breeding program, which do not necessarily increase yield but maintain yield at its ceiling via pathogen resistance. Notably, this study did not account for the economic impact of the maintenance breeding of the ARC breeding program, nor did it account for the increases in input costs (fungicides, pesticides, insecticides, etc.) that producers would have to incur if the breeding program did not continuously breed for biotic and abiotic stresses.

\section{Conclusion and Implications}

South African dry bean farmers who adopted the ARC breeding program's varieties during the period from 1972 to 2014 experienced a yield gain approximately equal to $23 \%$, which can be solely attributed to the genetic advancement from the ARC breeding program. These estimates result in South African dry bean farmers receiving an average annual economic benefit amounting to approximately R 31 million (in 2014 terms) for the same period. The benefit-cost ratio and the IRR provide evidence that the economic rate of return from the ARC breeding program is relatively high, although further assessment of these measures is difficult without comparable values for other public investments (the opportunity cost of funds).

The most tangible improvements of the ARC breeding program are the increased yields, but other substantial economic benefits are also evident in the yield losses avoided through resistance breeding, or "maintenance breeding." However, this study only valued yield increases and did not attempt to quantify the value of the maintenance breeding or to monetize the value of decreased yield variability; thus, the benefits estimated to producers in this study are conservative. In other words, without the ARC breeding program, dry bean yields could have remained at their low values in the 1980s or could have deteriorated and destabilized as pathogens may have drastically reduced yield while increasing yield variation as they overcame earlier resistance genes. Furthermore, climate models suggest that by the 2020s some 3.8 million ha of land suitable for bean production in Africa would benefit from a better drought tolerance package, and 7.2 million ha would benefit from heat tolerance (Buruchara et al., 2011). This observation implies the need for continuous funding for breeding efforts for a crop like dry beans because it provides micronutrients to more than 300 million people in the tropics. Although genetically modified (GM) maize is currently produced in South Africa, there are no commercially available GM dry beans. Given this, yield improvements in dry beans will most likely be marginal 
yearly improvements from public breeders like ARC. This further highlights the importance of public bean breeding for global food security.

Holding all other factors constant, the annual genetic gain attributed to the ARC breeding program has increased, and the returns to the breeding program continue to play a large role for dry bean farmers in increasing their dry bean yields. Given the estimates in this research, the benefits of the bean breeding program outweigh the costs by a multiple of about 6 , demonstrating that investments in the ARC breeding program have provided large and sustained economic benefits to dry bean farmers and consumers in South Africa. Furthermore, the increased bean yields experienced by South African farmers did not come at the expense of yield stability (or variance reduction). This benefits bean producers because it reduces the risks they incur in production from season to season, which can lead producers to increase investments in new technologies that are designed to increase overall productivity and food security. As importantly, South African bean consumers benefit from these higher yields (with no associated increase in yield variance) in the form of more stable food prices because they do not face the risk of sudden and sometimes sharp reductions in real income as a result of price shocks. The findings of this study indicate that not only are the returns on investment relatively high for the ARC bean breeding program, but they can also lead to increased food security though increased and stabilized yields.

\section{Supplementary material}

To view supplementary material for this article, please visit http://doi.org/10. 1017/aae.2016.46

\section{References}

Agricultural Research Council (ARC). Agricultural Research Council Annual Report 2013/2014. Pretoria, South Africa: ARC, 2014a.

- Report on the National Dry Bean Cultivar Trials. Potchefstroom, South Africa: ARCGrain Crops Institute, 2014b.

Alston, J., G. Norton, and P. Pardey. Science under Scarcity: Principles and Practice for Agricultural Research Evaluation and Priority Setting. Ithaca, NY: Cornell University Press, 1995.

Alston, J.M., M.C. Marra, P.G. Pardey, and T.J. Wyatt. "Research Returns Redux: A Metaanalysis of the Returns to Agricultural R\&D." Australian Journal of Agricultural and Resource Economics 44(June 2000):185-215.

Arrow, K.J. “The Economic Implications of Learning by Doing.” Review of Economic Studies 29,3(1962):155-173.

Brennan, J.P. "An Analysis of the Economic Potential of Some Innovations in a Wheat Breeding Programme." Australian Journal of Agricultural and Resource Economics 33(April 1989a):48-55. 
- "An Analytical Model of a Wheat Breeding Program." Agricultural Systems 31,4(1989b):349-366.

. "Measuring the Contribution of New Varieties to Increasing Wheat Yields." Review of Marketing and Agricultural Economics 52,3(1984):175-195.

Buruchara, R., R. Chirwa , L. Sperling, C. Mukankusi, J.C. Rubyogo, R. Muthoni, and M.M. Abang. "Development and Delivery of Bean Varieties in Africa: The Pan-Africa Bean Research Alliance (PABRA) Mode." African Crop Science Journal 19,4(2011): 227-245.

Consultative Group on International Agricultural Research (CGIAR). "Common Bean." Internet site: http://www.cgiar.org/our-strategy/crop-factsheets/beans/ (Accessed March $8,2016)$.

Crop Estimates Committee. Fourth Production Forecast for Summer Crops for 2014. Pretoria, South Africa: Department of Agriculture, Forestry and Fisheries, 2015. Internet site: http://www.wamis.org/countries/southafrica/Media\%20May\%202014. pdf (Accessed January 23, 2017).

Department of Agriculture, Forestry and Fisheries. Dry Bean Market Value Chain Profile. Arcadia, South Africa: Directorate of Marketing, Department of Agriculture, Forestry and Fisheries, 2012. Internet site: http://www.nda.agric.za/docs/AMCP/Dryb2012.pdf (Accessed October 16, 2015).

De Ron, A.M., R. Papa, E. Bitocchi, A.M. González, D.G. Debouck, M.A. Brick, D. Fourie, et al. "Common Bean." Grain Legumes. Handbook of Plant Breeding. A.M. De Ron, ed. New York: Springer Verlag, 2015, pp. 1-36.

Dlamini, T.S., L. Magingxa, and F. Liebenberg. "Estimating the Economic Value of the National Cultivar Trials in South Africa: A Case for Sorghum, Sunflower, Soybeans and Dry Beans." Paper presented at the Italian Association of Agricultural and Applied Economics (AIEAA) Fourth Congress, Ancona, Italy, June 11-12, 2015.

Evenson, R.E. "Economic Impacts of Agricultural Research and Extension." Handbook of Agricultural Economics. Vol. 1A. B.L. Gardner, and G.C. Rausser, eds. Amsterdam: North Holland Elsevier, 2001, pp. 573-628.

_. "Production Impacts of Crop Genetic Improvement." Crop Variety Improvement and Its Effect on Productivity: The Impact of International Agricultural Research. R.E. Evenson and D. Gollin, eds. Wallingford, UK: CABI, 2003, pp. 447-471.

Evenson, R.E., and D. Gollin, eds. Crop Variety Improvement and Its Effect on Productivity: The Impact of International Agricultural Research. Wallingford, UK: CABI, 2003.

Feyerherm, A.M., G.M. Paulsen, and J.L. Sebaugh. "Contribution of Genetic Improvement to Recent Wheat Yield Increases in the USA.” Agronomy Journal 76,6(1984):985990.

Fischer, R.A., and P.C. Wall. "Wheat Breeding in Mexico and Yield Increases." Journal of the Australian Institute of Agricultural Science 42(1976):139-148.

Food and Agriculture Organization of the United Nations (FAO). "FAOSTAT.” Internet site: http://faostat.fao.org/ (Accessed October 26, 2015).

Gollin, D. Impacts of International Research on Intertemporal Yield Stability in Wheat and Maize: An Economic Assessment. Mexico, DF: CIMMYT, 2006.

Holland, J.B., and E.T. Bingham. "Genetic Improvement for Yield and Fertility of Alfalfa Cultivars Representing Different Eras of Breeding.” Crop Science 34,4(1994):953957.

Huffman, W.E., and R.E. Evenson. Science for Agriculture: A Long-term Perspective. Ames, IA: Blackwell, 2006. 
Hurley, T.M., X. Rao, and P.G. Pardey. "Re-examining the Reported Rates of Return to Food and Agricultural Research and Development." American Journal of Agricultural Economics 96,5(2014):1492-1504.

International Monetary Fund (IMF). "International Financial Statistics (IFS). IMF elibrary Data." Internet site: http://data.imf.org/?sk=5DABAFF2-C5AD-4D27-A1751253419C02D1 (Accessed October 16, 2015).

Johnson, N.L., D. Pachico, and C.S. Wortmann. "The Impact of CIAT's Genetic Improvement Research on Beans." Crop Variety Improvement and Its Effect on Productivity: The Impact of International Agricultural Research. R.E. Evenson and D. Gollin, eds. Wallingford, UK: CABI, 2003, pp. 257-274.

Just, R.E., and R.D. Pope. "Production Function Estimation and Related Risk Considerations." American Journal of Agricultural Economics 61,2(1979):276-284.

Kalyebara, R., D. Andima, R. Kirkby, and R. Buruchara. Improved Bean Varieties and Cultivation Practices in Eastern-Central Africa Economic and Social Benefits. Cali, Columbia: Centro Internacionale de Agricultura Tropical, 2008.

Larochelle, C., J. Alwang, G.W. Norton, E. Katungi, and R.A. Labarta. "Impacts of Improved Bean Varieties on Poverty and Food Security in Uganda and Rwanda." Crop Improvement, Adoption, and Impact of Improved Varieties in Food Crops in SubSaharan Africa. T. Walker and J. Alwang, eds. Wallingford, UK: CGIAR-CABI, 2015, pp. 314-337.

Lobell, D.B., K.G. Cassman, and C.B. Field. "Crop Yield Gaps: Their Importance, Magnitudes, and Causes." Annual Review of Environment and Resources 34(2009):179_ 204.

Marasas, C.N., M. Smale, and R.P. Singh. “The Economic Impact of Productivity Maintenance Research: Breeding for Leaf Rust Resistance in Modern Wheat.” Agricultural Economics 29,3(2003):253-263.

Maredia, M.K., R. Bernsten, and C. Ragasa. "Returns to Public Sector Plant Breeding in the Presence of Spill-ins and Private Goods: The Case of Bean Research in Michigan.” Agricultural Economics 41,5(2010):425-442.

Nalley, L.L., and A.P. Barkley. "Using Portfolio Theory to Enhance Wheat Yield Stability in Low-Income Nations: An Application in the Yaqui Valley of Northwestern Mexico." Journal of Agricultural and Resource Economics 35,2(2010):334-347.

Nalley, L.L., A.P. Barkley, and F. Chumley. "The Impact of the Kansas Wheat Breeding Program on Wheat Yields, 1911-2006." Journal of Agricultural and Applied Economics 40,3(2008a):913-925.

Nalley, L.L., A.P. Barkley, J.M. Crespi, and K.D. Sayre. "The Global Impact of the CIMMYT Wheat Breeding Program." Journal of International Agricultural Trade and Development 5,1(2008b):11-29.

Salmon, S.C. "Analysis of Variance and Long-Time Variety Tests of Wheat." Agronomy Journal 43,11(1951):562-570.

Siddiq, M., and M.A. Uebersax. "Dry Beans and Pulses Production and Consumption-an Overview." Dry Beans and Pulses: Production, Processing and Nutrition. M. Siddiq and M.A. Uebersax, eds. Oxford, UK: Wiley-Blackwell, 2012, pp. 3-22.

Singh, S.P., H. Terán, M. Lema, D.M. Webster, C.A. Strausbaugh, P.N. Miklas, H.F. Schwartz, and M.A. Brick. "Seventy-Five Years of Breeding Dry Bean of the Western USA." Crop Science 47,3(2007):981-989.

Strauss, F.M. Die evaluasie van fungisiede vir die beheer van roes (Uromyces appendiculatus) op droebone (Phaseolus vulgaris L.) [The Evaluation of Fungicides for the Control of 
Rust (Uromyces appendiculatus) on Dry Beans (Phaseolus vulgaris L.)]. Potchefstroom, South Africa: ARC-Grain Crops Institute, 1999, Project Report 1999.

Strauss, F.M., and L. Killian. Die evaluasie van swamdoders vir die beheer van roes op droebone [The Evaluation of Fungicides for the Control of Rust on Dry Beans]. Potchefstroom, South Africa: ARC-Grain Crops Institute, 1996, Project Report 1995/96.

Tack, J.B., A.P. Barkley, and L.L. Nalley. "Estimating Yield Gaps with Limited Data: An Application to United States Wheat." American Journal of Agricultural Economics 97,5(2015):1464-1477.

Thirtle, C., R.F. Townsend, J. Amadi, A. Lusigi, and J. van Zyl. "The Rate of Return on Expenditures of the South African Agricultural Research Council (ARC)." Agrekon 37,4(1998):612-622.

Timmer, P. "The Macroeconomics of Food and Agriculture." International Agricultural Development. C. Eicher, ed. Baltimore, MD: Johns Hopkins University Press, 1998, pp. 187-211.

Traxler, G., J. Falck-Zepeda, J.I. Ortiz-Monasterio R., and K. Sayre. "Production Risk and the Evolution of Varietal Technology." American Journal of Agricultural Economics 77,1(1995):1-7.

Waddington, S.R., J.K. Ransom, M. Osmanzai, and D.A. Saunders. "Improvement in the Yield Potential of Bread Wheat Adapted to Northwest Mexico." Crop Science 26,4(1986):698-703. 